\title{
TELAAH FATWA MUI NO. 10 TAHUN 2008 \\ TENTANG NIKAH DI BAWAH TANGAN BERBASIS \\ SADD AL-DZARĪ‘AH DAN KEADILAN GENDER
}

\author{
Moh. Mujibur Rohman \\ Prodi Hukum Keluarga Islam Pascasarjana IAIN Madura \\ mujibur.rohman6568@gmail.com \\ Mohsi \\ STAI Miftahul Ulum Pamekasan \\ silamobsi@gmail.com \\ Miftahul Ulum \\ Institut Agama Islam Negeri Jember \\ miftabul_ulum2001@iain-jember.ac.id
}

\begin{abstract}
Abstrak
Nikah bawah tangan menjadi isu krusial dalam hukum Islam kekinian. Sadd al-dzaríah merupakan salah satu bentuk metode ijtihad yang yang dapat digunakan sebagai landasan istimbath albukm (pengambilan hukum). Secara istilah sadd al-drari'ab merupakan pembahasan seputar upaya untuk menghalangi dan memblokade semua akses dan kemungkinan dari suatu perbuatan tertentu yang pada dasarnya diperbolehkan maupun dilarang untuk mencegah terjadinya segala jenis kerusakan dan kemudaratan. Teori pencegahan ini sering disebut sebagai langkah preventif dalam meminimalisir atau bahkan menutup jalan terjadinya kemudaratan suatu perbuatan. Penelitian ini menggunakan pendekatan kualitatif, dengan studi pustaka. penelitian pustaka mengacu kepada literatur-literatur sebagai basic of anlisis atas topik yang dijadikan obyek penelitian. Salah satu bentuk langkah preventif pemerintah Indonesia dalam bidang hukum perkawinan adalah menjamin ketertiban dalam sebuah perkawinan melalui undang-undang pencatatan perkawinan, sebagaimana pasal 5 ayat (1) Kompilasi Hukum Islam (KHI) yang berbunyi "Agar terjamin ketertiban perkawinan bagi masyarakat islam setiap perkawinan barus dicatat". Langkah ini bertujuan membentuk keadilan gender, agar diskriminasi terhadap kaum perempuan dalam praktik perkawinan tidak lagi terjadi.
\end{abstract}

Kata Kunci: Nikah Bawah Tangan, Fatwa MUI, Keadilan Gender. 


\begin{abstract}
Underhand marriage is a crucial issue in contemporary Islamic law. Sadd al-dzari'ah is a form of the ijtihad method which can be used as a basis for istimbath al-hukm. In terms of sadd aldzari'ah, it is a discussion about efforts to block and block all access and the possibility of a certain act which is basically allowed or prohibited to prevent all kinds of damage and damage. This theory of prevention is often referred to as a preventive step in minimizing or even blocking the path for the occurrence of an act of oblivion. This research uses a qualitative approach, with literature study. literature research refers to the literature as the basic of analysis on the topic which is the object of research. One form of preventive measures taken by the Indonesian government in the field of marriage law is to guarantee order in a marriage through the marriage registration law, as in Article 5 paragraph (1) Islamic Law Compilation (KHI) which reads "In order to ensure orderliness of marriage for the Islamic community every marriage must noted ". This step aims to establish gender justice, so that discrimination against women in the practice of marriage no longer occurs.
\end{abstract}

Keywords: Underhanded Marriage, MUI Fatwa, Gender Justice. 


\section{Moh. Mujibur Rohman, Mohsi dan Miftahul Ulum}

\section{Pendahuluan}

Nikah bawah tangan menjadi isu hukum faktual dan kontekstual. Pengistilalahan ini ditengarai oleh adanya hukum yang mengatur tentang pencatatan nikah, melalui aturan hukum UU No. 22 tahun 1946. Secara legitimitas setiap pernikahan yang dilangsungkan oleh bangsa Indonesia, harus dicatatakan di kantor urusan Agama. Secara praktis, Nikah di bawah tangan merupakan nikah yang tidak dicatatkan pada instansi terkait, tapi dilaksanakan menurut agama dan kepercayaan masing-masing, selain bentuk pernikahan yang demikai ada juga adalah pernikahan yang dilakukan melalui sembunyi-sembunyi dan tidak diketahui oleh orang sekitar.

Yurisprudensi fiqh klasik tidak ditemukan pengistilahan nikah bawah tangan, karena dalam fiqh Islam pernikahan adalah suatu akad yang dapat menghalalkan bentuk wathi berdasarkan rukun yang lima yaitu Calon suami, calon istri, saksi, wali, sihat, sedangkan pencatatan nikah dalam fiqh Islam klasik belum terekam, sehingga tampak belum menjadi fokus perbincangan para fuqoha`. Nikah bawah tangan didefnisikan sebagai bentuk nikah tanpa adanya suatu pencatatan pada instansi yang telah ditentukan oleh peraturan perundangundangan.

Sebagai lembaga keagamaan Islam, Majelis Ulama`Indonesia (MUI) pada tahun 1980 pernah mengeluarkan fatwa atas praktik pernikahan yang tidak dicatatkan terse- but. Kesimpulan fatwanya memnyimpulkan bahwa pernikahan dengan model bawah tangan hukumnya sah, karena telah terpenuhi syarat dan rukunnya, tetapi haram jika terdapat mafsadat. Pada tahun 2008, MUI juga mengeluarkan fatwa tentang kasus yang sama, dengan hasil kesimpulan bahwa pernikahan bawah tangan adalah sah, dan wajib dicatatakan. Fatwa ini bernomor 10 tahun 2008. Kesimpulan ini berdasarkan pada diktum-diktum konsiderannya, dengan mengacu pada berapa ketentuan-ketentuan dalam fiqh klasik tentang posisi pemerintah dan wajibnya taat pada pemerintah, sehingga kesimpulan mewajibkan pencatatan perkawinan adalah berdasarkan ketentuan tersebut.

Diskursus fiqh tentang nikah bawah tangan, sekurang-kurangnya ada tiga kelompok yang memberikan sikap tentang hukumnya. Kelompok pertama membolehkan dengan prinsip bahwa pernikahan itu untuk mencegah timbulnya pelanggaran hukum. kelompok kedua melarang perniakahan bawah tangan, dengan alasan lebih banyak mafsadahnya, serta tidak mentaati aturan hukum, serta menimbulkan dualism hukum. kelompok ketiga ada diposisi tafsil dan moderat dengan catatan harus sesuai dengan hukum positif.

Penelitian ini akan mengungkap sejauh mana keadilan gender yang diterjemahkan dalam fatwa MUI tentang nikah bawah tangan. Sekaligus menakar bentuk keadilan

1 Happy Susanto, Nikah Siri Apa Untungnya, (Jakarta: Visimedia, 2007), 26-28. 
gender dari fatwa tersebut, apalagi ketika ditinjau dari konsep sad al-Dzariah.

Penelitian ini menggunakan liberary research, dengan konsep ushuli, karena terfokus pada kajian atas fatwa MUI yang membolehkan nikah bawah tangan, serta mewajibkan mencatatnya. Pendekatan ushuli adalah dalam upaya untuk memberikan sudut pandang baru yang berbasis maslahah dan keadilan gender. Pendekatan ushuli yang dipakai adalah pendekatan sad al-Dzariah, dimana konsep ini seringkali dipakai oleh para pakar untuk mengetahui dan merumuskan hukum yang konstekstual.

\section{Pembahasan}

\section{Fatwa Majelis Ulama Indonesia tentang}

\section{Nikah di Bawah Tangan}

Majelis Ulama Indonesia (selanjutnya disingkat MUI) merupakan sebuah instansi non pemerintah sebagai wadah para ulama dan cendekia muslim di Indonesia dalam melakukan musyawarah mufakat untuk mencetuskan sebuah hukum terkait persoalan-persoalan keagamaan serta kebangsaan yang timbul ditengah-tengah masyarakat Indonesia. Ketetapan hukum yang sudah disepakati bersama atau kolektif (ijtihad jama'i) dalam forum musyawarah ulama tersebut tertuang dalam suatu keputusan yang disebut dengan fatwa yang dikeluarkan oleh Komisi Fatwa MUI.
Secara bahasa (lughat) fatwa merupakan suatu jawab atas problema yang terjadi di tengah masyarakat. Namun, jika fatwa sendiri pengguaannya diartikan kedalam kajian hukum Islam, ialah suatu jawaban bagi orang yang bertanya (meminta fatwa) tentang syariat, baik jawaban tersebut ragu-ragu atau ditujukan secara jelas untuk kalangan pribadi atau umum. ${ }^{2}$ Proses penetapan fatwa MUI didasarkan atas al-Qur'an, Hadis, Ijma' dan Qiyas serta melakukan pengkajian terlebih dahulu terhadap pendapat imam madzhab terkait hal yang akan difatwakan.

Berbeda dengan produk lain yang memiliki sifat mengikat. Secara toritis fatwa tidak bersifat mengikat, seperti halnya keputusan pengadilan dan undang-undang. Fatwa akan ada atau terbentuk bila sebelumnya terdapat permasalahan hukum yang belum jelas atau kasus baru (waqiiyah) yang sebelumnya tidak terjawbkan (kasuistik). Dalam mengeluarkan fatwanya MUI dan Komisi Fatwa yang dinaunginya senantiasa melakukan penalaran dengan mempertimbangkan kemaslahatan secara umum (mashalih al-'ammah) serta mengacu kepada maqashid al-syari'ah. ${ }^{3}$

Istimbath al-Ahkam (penetapan hukum) yang dilakukan MUI serta Komisi Fatwa di bawahnya masih mengacu pada tradisi figh

${ }^{2}$ Rohadi Abdul Fatah, Analisis Fatwa Keagamaan dalam Fikih Islam (Jakarta:Bumi Aksara, 2006), 9.

3Pedoman dan Prosedur Penetapan Fatwa Majelis Ulama Indonesia 


\section{Moh. Mujibur Rohman, Mohsi dan Miftahul Ulum}

ulama sunni. Dimana metodologi penetapan hukum selalu bersifat dinamis. Ada empat hal berbeda dalam melakukan istimbath alabkam. Pertama; mashadir al-abkam, merupakan metode istimbath dengan mengacu pada sumber hukum yang bersifat tekstual. Seperti al-Qur'an, hadis, atsar al-sababah dan ijma' (sekalipun ijma' ulama yang tidak ada sandarannya namun dengan konteks hukum yang sama). Kedua; manahij istmbath al-abkam, ialah sebuah instrumen metodologis dalam merumuskan kesimpulan hukum. Seperti qiyas, ilhaq (meng-qiyas permasalahn kontemporer dengan pendapat ulama klasik) dan istqra' (deduksi). Ketiga; al-adawat, ialah data baru yang digunakan sebagai instrumen menentukan sebuah hukum. Seperti, 'urf (kebiasaan), al-maqashid, al-mashalih, bukm alhakim wa al-qadhi (keputusan Pemerintah dan peradilan) serta sadd al-drari ah. Keempat; prinsip-prinsip dasar jurisprudensial yang digunakan sebagai instrumen penentuan hukum. Seperti qawaid al-fiqbiyah dan lainnya. ${ }^{4}$

Di Indonesia, fatwa MUI merupakan buah ijtihad ulama dalam menyikapi persoalan (dalam bidang; keagamaan, ilmu pengetahuan, teknologi, sosial kemasyarakatan, budaya, ekonomi dan politik). Oleh karenanya, fatwa MUI yang merupakan suara ulama dalam menjawab persoalan baru,

${ }^{4}$ Iffatul Umniati Ismail, "Telaah Kritis Metodologi Istimbath MUI; Studi Kasus Fatwa Tentang Golput" Media Shariah, Vol. XIII No. 1 (Januari-Juni 2011), 76. berkewajiban mengkaji kembali sumber utama ajaran Islam serata khazanah pemikiran Islam klasik dengan spirit yang baru. Sehingga dengan hal itu, keberadaan ulama (baca fatwa MUI) bisa diyakini dapat merekonstruksi kembali pemahaman khazanah keislaman dengan cara menyesuaikan problem-problem kekinian sesuai dengan perkembangan zaman tanpa menyalahi kaidah ajaran Islam. ${ }^{5}$

Kaitannya dengan persoalan hukum keluarga, MUI telah mengeluarkan banyak fatwa dalam menjawab problematika hukum yang terjadi di tengah-tengah masyarakat. Salah satu fatwa MUI dalam bidang hukum keluarga adalah nikah di bawah tangan. Berdasarkan hasil keputusan forum ijtima' ulama komisi fatwa bahwa yang di maksud "nikah di bawah tangan" adalah pernikahan yang terpenuhi semua rukun dan syarat yang ditetapkan dalam fiqh (hukum Islam). Namun, nikah tersebut tanpa pencatatan resmi di instansi berwenang sebagai mana diatur dalam perundang-undangan. ${ }^{6}$ Menurut K.H. Ma'ruf Amin Penggunaan istilah nikah di bawah tangan bertujuan untuk membedakan antara nikah siri $^{7}$ (yang dikenal masyarakat),

${ }^{5}$ Majelis Ulama Indonesia, Himpunan Fatwa Majelis Ulama Indonesia Tentang Ibadah (Jakarta: Erlangga, 2015), xxiv-xxv.

${ }^{6}$ Fatwa Majelis Ulama Indonesia Nomor 10 Tahun 2008 Tentang Nikah di Bawah Tangan, 531.

${ }^{7}$ Pengertian "nikāh siri" dikalangan masharakat masih terjadi perbedaan definisi. Ada yang mendefinisikan sebagai nikah tanpa wali, ada yang mengatakan nikah yang terpenuhi sharat dan rukunya, hanya saja tidak dicatatkan pada instansi berwenang seperti Kantor Urusan Agama (KUA). Selain itu, ada pula pendapat bahwa nikeăh siri merupakan pernikahan yang 
serta istilah ini lebih sesuai dengan ketentuan agama Islam. ${ }^{8}$

Nikah di bawah tangan -tidak tercatat pada instansi berwenang- seringkali dijumpai dikalangan masyarakat utamanya dikalangan masyarakat pedesaan yang tingkat keagamaanya begitu tinggi. Hal ini diakibatkan adanya pencatatan pernikahan bukanlah suatu hal yang menjadi syarat sahnya sebuah pernikahan. Terkait hal tersebut, komisi fatwa MUI merumuskan hukum nikah di bawah tangan sebagai nikah yang sah, karena telah terpenuhi syarat dan rukunnya, tetapi akan berstatus haram bila terdapat hal mudharat yang ditimbulkan dari pernikahan tersebut. Oleh karenanya pernikahan harus dicatatkan secara resmi pada instansi berwenang sebagai langkah preventif untuk menolak dampak negatif/mudharat (saddan lidzdzaríab).

Dalam fatwanya, MUI melakukan istimbath al-hukm dengan berdasar mashadir alabkam (sumber hukum materil) yakni alQur'an dan hadist Nabi serta menggunakan

dilakukan secara sembunyi karena berbagai pertimbangan. Misalnya, menikahi wanita lain sebagai isteri kedua yang dilakukan secara sembunyi karena tidak mau mendapatkan stigma negatif dari masharakat. Lihat: Vivi Kurniawati, Nikah Siri (Jakarta: Rumah Fiqih Publishing, 2019), 10-14.

${ }^{8}$ M. Asrorun Ni'am Sholeh, Metodologi Penetapan Fatwa Majelis Ulama Indonesia; Penggunaan Prinsip Pencegahan dalam Fatwa, 222-223.

${ }^{9}$ Fatwa Majelis Ulama Indonesia Nomor 10 Tahun 2008 Tentang Nikah di Bawah Tangan, 531532. prinsip dasar jurisprudensial yang berupa qawaid fiqhiyah. Diyakini atau tidak, adanya praktik nikah di bawah tangan seringkali menyebabkan ketimpangan hukum terhadap kaum wanita (istri) dan anak yang dilahirkan. Terdapat banyak mudharat atau dampak negatif dari adanya pernikahan tersebut utamanya dalam masalah keperdataan.

Dalil yang di gunakan MUI, untuk membendung terjadinya nikah bawah tangan adalah QS. Al-Nisā' (4): 59, ${ }^{10}$ yakni adanya kewajiban taat terhadap pemerintah (ulil amri). Al-Marāghi menegaskan yang dimaksud ulil amri adalah pemerintah (pemimpin). Baik pimpinan tertinggi atau yang ada di bawahnya, dengan tugasnya memelihara kemaslahatan umat manusia. Dengan demikian aturan-aturan yang dibuatnya wajib ditaati selagi aturan tersebut tidak bertentangan dengan al-Qur'an dan hadis. ${ }^{11}$ Sejatinya pemerintah sudah mengharuskan adanya

${ }^{10} \mathrm{Al}-\mathrm{Qur} a ̄ n$, al-Nisā’’ (4): 2:

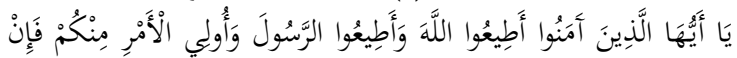

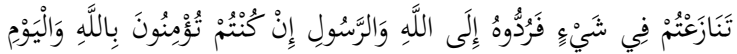

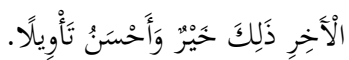

Artinya: Hai orang-orang yang beriman, taatilah Allab dan taatilah Rasaul-Nya dan Ulil amri diantara kamu. Kemudian jika kamu berlainan pendapat tentang sesuatu, maka kembalikeanlab ia kepada Allab (al-Qur'an) dan Rasul (sunnahnya), jika kamu benar-benar beriman kepada Allab dan hari akhir. Yang demikian itu lebih utama (bagimu) dan lebib baik akibatnya.

${ }^{11}$ Ahmad Musthafa al-Marāghi, Tafsìr alMaräghi, Juz. 5 (Mesir: t.p., 1946), 72. 


\section{Moh. Mujibur Rohman, Mohsi dan Miftahul Ulum}

pencatatan perkawinan ${ }^{12}$ di instansi berwenang bagi yang hendak melaksanakan pernikahan. Yakni di Kantor Urusan Agama (bagi umat beragama Islam). Peraturan pencatatan perkawinan itu sendiri sudah tertuang dalam Pasal 1 ayat (1) Undnag-Undang No. 22 Tahun 1946 Tentang Pencatatan Perkawinan, Talak dan Rujuk. ${ }^{13}$ Pasal 2 Ayat (1) dan (2) Undang-Undang No. 1 Tahun 1974 Tentang Perkawinan ${ }^{14}$ dan Pasal 5 Ayat (1) Kompilasi Hukum Islam (KHI). ${ }^{15}$

Mematuhi undang-undang yang diberlakukan oleh pemerintah terkait adanya keharusan mencatat perkawinan yang sifatnya mengikat, selain sebagai taat terhadap pemerintah (ulil amri) juga harus dipandang sebagai bentuk baru dalam mengumukan pernikahan (ilan al-nikah) agar tidak terjadi

${ }^{12}$ Neng Djubaidah mengemukanan bahwa Pencatatan Perkawinan merupakan pencatatan atas suatu perkawinan yang sah menurut hukum Islam, yakni perkawinan yang memenuhi rukun dan syarat perkawinan sesuai syari'at Islam yang dilakukan di Kantor Urusan Agama (KUA) kecamatan setempat. Lihat: Neng Djubaidah, Pencatatan Perkawinan dan Perkawinan Tidak Dicatat Menurut Hukum Tertulis di Indonesia dan Hukum Islam (Jakarta: Sinar Grafika, 2012), 3.

${ }^{13}$ Pasal 1 ayat (1) UU No. 22/1946 Tentang Pencatatan Perkawinan, Talak dan Rujuk: "Nikah yang dilakukan menurut agama Islam, selanjutnya disebut nikab, diawasi oleh pegawai pencatat nikeah yang diangkat oleh Menteri Agama atau pegawai yang ditunjuk olehnya. Talak dan rujuk yang dilakukan menurut agama Islam, selanjutnya disebut talak dan rujuk, diberitabukan kepada pegawai pencatat nikab". lihat juga dalam dalam Mohsi, M. (2019). pencatatan perkawinan sebagai rekonseptualisasi system saksi perkawinan berbasis maslahah. Al-'Adalab: Jurnal Syariah dan Hukum Islam, 4(2), 134-148.

${ }^{14}$ Pasal 2 ayat (1) dan (2) UU No. 1/1974 Tentang Perkawinan: Perkawinan adalah sah, apabila dilakukan menurut bukum masing-masing agamanya dan kepercayaannya itu. Tiap-tiap perkawinan dicatat menurut peraturan perundang-undangan yang berlaku.

${ }^{15}$ Pasal 5 ayat (1) Kompilasi Hukum Islam (KHI): "Agar terjamin ketertiban perkawinan bagi masyarakat Islam setiap perkawinan harus dicatat". pernikahan secara rahasia. Nabi Saw bersabda :

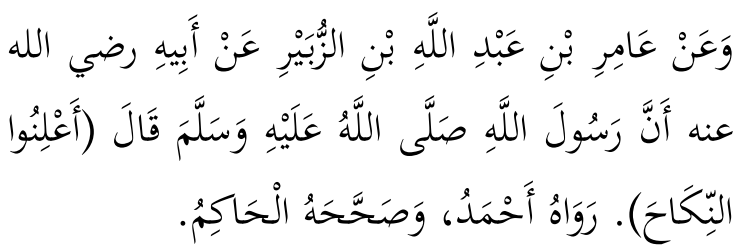

Artinya: Diceritakan hadis dari Amir bin Abdullāh bin Zubair dari bapaknya babwa Rasulullah Saw. berkata: "Umumkanlah sebuah pernikahan". (HR. Ahmad dan dianggap hadis sahih oleh imam Hākim). ${ }^{16}$

Hadis ini menegaskan bahwa Nabi Saw. sangat menganjurkan yang namanya ilan al-nikah (mengumumkan pernikahan). Adanya pencatatan perkawinan perlu dipandang sebagai langkah preventif (pencegahan) agar tidak terjadi pernikahan yang tersembunyi. Dengan adanya i'lan al-nikah (mengumumkan pernikahan) pada masa Nabi Saw. Menunjukkan bahwa spirit dan substansi yang ingin dicapai dari adanya pencatatan perkawinan telah dimanifestasikan meski dalam bentuk yang sangat sederhana. ${ }^{17}$ Berdasarkan pendapat yang kuat i'lan al-nikah dipandang sebagai salah satu syarat sahnya sebuah pernikahan, karena yang menjadi pembeda antara pernikahan dengan perzinahan adalah dari segi mengumumkannya. Imam al-Zuhri menghukumi fardhu. Menurutnya pernikahan yang terpenuhi syarat dan rukunya namun tidak di-

${ }^{16} \mathrm{Ibn}$ Hajar al-'Asqalāni, Bulügh al-Marām fì Adillat al-Ahkām (Surabaya: Nurul Huda, t.t.), 211.

${ }^{17}$ Moh. Mujibur Rohman \& Mohsi, "Konstruksi I'lan al-Nikah dalam Fiqh Pancasila (Telaah Pencatatan Perkawinan Perspektif Sadd al-Dzari'ah" Ulumuna; Jurnal Studi Keislaman, Vol. 3 No. 1 (Juni 2017), 21. 
umumkan, maka pernikahan itu dipisahkan. Begitu pula bila dua orang saksinya ikut merahasiakan kepada khalayak ramai, maka pernikahan itu harus dipisah. ${ }^{18}$

Tujuan adanya pencatatan perkawinan sendiri adalah untuk menjamin ketertiban perkawinan, sebagaimana pasal 5 ayat (1) Kompilasi Hukum Islam (KHI). Oleh karenanya secara eksplisit dijaman nabi belum ada yang namanya pencatatan perkawinan namun secara implisit kandungan ilan alnikah sudah mengarah kepada ketertiban perkawinan agar mendapat legalitas yang sah serta diketahui oleh masyarakat. Khoiruddin Nasution menyatakan bahwa terdapat perubahan 'illah yang sama antara masa Nabi dengan masa sekarang. Tllah pada masa Nabi Saw. adalah adanya pengakuan masyarakat dan penjaminan hak dalam sebuah pernikahan oleh karenanya Nabi menganjurkan yang namanya ilan al-nikah yang kemudian dimanifestasikan dalam bentuk walimah al'ursy. Sedang pada masa sekarang, jaminan hak dan pengakuan masyarakat tidak cukup dengan adanya walimah al-ursy atau i'lan alnikah tetapi dibutuhkan bukti tertulis (akta nikah) sebagai bukti otentik. ${ }^{19}$

\footnotetext{
${ }^{18}$ Vivi Kurniawati, Nikah Siri, 29

${ }^{19}$ Khoiruddin Nasution, Hukum Perdata (Keluarga) Islam Indonesia dan Perbandingan Hukum Perkawinan di Dunia Muslim (Yogyakarta:ACAdeMIA+Tazzafa, 2008), 366.
}

Berdasarkan hal tersebut adanya fatwa MUI atas keharaman nikah bawah tangan dengan mempertimbangkan kecendrungan terjadinya mudlarah. Hal ini juga berdasar qawaid fiqbiyah yang sejalan dengan prinsip umum sadd al-dzaríab:

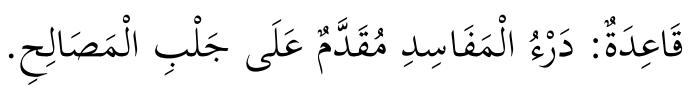

"Menolak kerusakan (mafäsid) lebih diutamakan dari pada memperbitungkan kebaikan (mashlahab)". ${ }^{20}$

Kaidah fiqh ini merupakan prinsipprinsip dasar jurisprudensial yang konotasinya searah dengan aplikasi sadd aldzaríah itu sendiri. al-Suyuthi mengatakan bila kebaikan dan kerusakan keduanya samasama bertentangan maka yang didahukuan adalah menolak kerusakan tersebut. ${ }^{21} \mathrm{Me}$ nolak hal negatif sebagai dampak dari adanya nikah bawah tangan hukumnya adalah wajib, status pernikahannya sah namun haram ketika terjadi hal mudharat.

Tujuan mulia sebuah perkawinan tidak lain adalah terciptanya ikatan perkawinan sakinah mawaddah wa rahmah. Sebagaimana tertuang di dalam QS. al-Rūm (30): 22, ${ }^{22}$ ser-

${ }^{20} \mathrm{Abi}$ Bakar bin Abi al-Qâsim al-Ahdal, alFaräid al-Babiyah 'ala Nažbmi Qawāid al-Fiqhiyah (Pasuruan: Pustaka Sidogiri, 2009), 48.

${ }^{21}$ Jalāl al-Dīn Abd Rahmān bin Abī Bakar alSuyūthi, al-Asybah wa al-Naz̧äir (Semarang: Pustaka Semarang, t.t., 120 .

22Al-Qur'ān, 30:22:

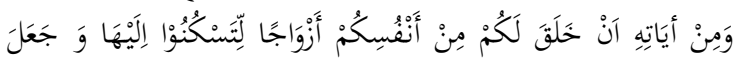

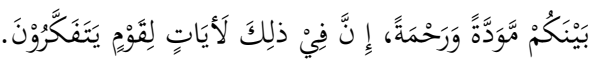


ta Pasal 1 Undang-Undang Perkawinan No. 1 tahun 1974 tentang Perkawinan. ${ }^{23}$ Berdasar tujuan pernikahan tersebut, maka adanya ikatan perkawinan menjaga keutuhan rumah tangga dengan mencapai tingkatan sakinah mawaddah wa rahmah, merupakan suatu keharusan. Oleh karenanya, Praktik nikah bawah tangan sudah menyimpang dari sakinah mawaddah wa rabmah, hal ini disebebakan pernikahan tersebut cenderung membawa konflik serta merugikan salah satu pihak dari pelaku hukum utamanya istri dan anak yang dilahirkan.

\section{Sadd al-Dzarīah; Langkah Preventif Berbasis Keadilan Gender}

Penggunaa Sadd al-D zariah memang tidak ada dalil yang jelas dan pasti baik dalam bentuk nash maupun ijma' ulama tentang boleh atau tidaknya menggunakan sadd aldzarí $a$ ah. Dasar pengambilannya hanya semata-mata ijtihad, dengan berdasarkan tindakan hati-hati dalam beramal dan jangan sampai melakukan perbuatan yang dapat menimbulkan kerusakan. ${ }^{24}$ Tidak semua ulama sepakat atas penggunaan sadd al-draríab sebagai metode dalam menetapkan hukum.

Artinya: "Dan di antara tanda-tanda kekuasaan-Nya ialah Ia menciptakan untuk kamu istri-istri dari jenismu sendiri, supaya kamu cenderung dan merasa tenteram kepadanya dan dijadikan-Nya di antara kamu rasa kasib dan sayang. Sesunggubnya pada yang demikian itu benar-benar terdapat tanda-tanda bagi orang-orang yang mengetabui".

${ }^{23}$ Pasal 1 UUP No. 1/1974 tentang Perkawinan: "Perkawinan ialah sebuah ikatan labir batin antara seorang pria dengan seorang wanita sebagai suami istri dengan tujuan membentuk. keluarga (rumah tangga) yang bahagia dan kekal berdasarkan Ketuhanan Yang Maba Esa".

${ }^{24}$ Amir Sharifuddin, Ushul Figh, 429.
Perkawinan yang tidak dicatat seringkali menimbulkan dampak mudarat atau negatif utamanya bagi kaum perempuan serta anak yang dilahirkan. Oleh karenanya, pencatatan perkawinan merupakan langkah preventif berkeadilan gender, untuk menghilangkan diskriminasi terhadap wanita dalam praktik perkawinan. Hingga saat ini pernikahan tidak tercatat masih terjadi di masyarakat. Hal ini dibuktikan dengan banyaknya kasus nikah siri (rahasia) atau nikah bawah tangan yang masih tetap berlaku dikalangan masyarakat, utamanya di daerah pedesaan. dimana ketaatan beragama begitu tinggi sedang kepatuhan akan konsekuensi hukum bernegara kurang, akibatnya tidak ada keseimbangan antara hukum keagamaan dengan hukum kenegaraan.

Masyarakat pedesaan menganggap cukup dengan adanya syarat dan rukun perkawinan yang sudah ditetapkan dalam kitab-kitab fiqh klasik, mereka meninggalkan pencatatan perkawinan sebagai syarat administratif kenegaraan. Akibatnya mereka yang enggan mencatatkan pernikahannya harus melakukan itsbat nikah (permohonan pengesahan nikah) apabila terjadi hal-hal dalam bahtera rumah tangganya. "Data yang diperoleh Kementrian Agama Kota Palu Sulawesi Tengah, selama tiga tahun terkahir sejak tahun 2016 hingga 2019 tercatat 537 pasangan suami-istri (pasutri) yang mengikuti sidang isbat nikah di pengadilan palu". 
Pernikahan tidak tercatat (sirri dan nikah bawah tangan) tidak hanya terjadi dikalangan masyarakat pedesaan saja, namun seringkali menimpa kalangan elit. Salah satu contoh pernikahan yang tidak tercatatat pada instansi berwenang yang mengakibatkan kaum wanita menerima kerugian, yaitu kasus perkawinan usia dini dan sirri yang terjadi pada tahun 2006, antara putra mahkota kerajaan kelantan Malaysia, Tengku Temenggong Muhammad Fakhry (31 tahun) dengan Manohara Odelia Pinot (16 tahun), wanita keturunan Perancis-Indonesia berakhir dengan perceraian pada tahun 2008 (Kompasiana, 2011). Satu tahun yang lalu, sebuah kasus datangnya dari artis Nikita Mirzani yang memang tak pernah lepas dari konflik pernikahan, selain konflik dengan Dipo Latief, Nikita Mirzani juga diketahui bermasalah dengan Sajad Ukra. Konflik pernikahan Nikita Mirzani dengan Dipo Latief mengakibatkan anak yang lahir dari pernikahan di bawah tangan antara keduanya tidak bisa diakui secara perdata (negara) dan menuai berbagai konflik hingga hak asuh dan biaya hidup anak tersebut harus ditanggung Nikita Mirzani.

Dalam praktik perkawinan sirri atau nikah bawah tangan, wanita selalu mengalami tindak ketidak adilan. Undang-undang Nomor 7 Tahun 1984 telah mengatur secara jelas mengenai perlakuan yang adil terhadap perempuan, baik dari segi penegakan hukum maupun mengupayakan adanya perlakuan yang sama antara perempuan dan laki-laki dalam mengakses keadilan, kebenaran dan pemulihan. Pasal 16 ayat (2) menentukan bahwa: pertunangan dan perkawinan seorang anak tidak akan mempunyai akibat hukum, dan harus diambil semua tindakan yang diperlukan, termasuk perundang-undangan, untuk menetapkan batas usia perkawinan dan untuk mendaftarkan perkawinan pada kantor catatan sipil yang resmi.

Adanya dampak negatif atau mudarat, dimana wanita selalu dirugikan dalam praktik perkawinan tidak tercatat. Membuat pemerintah mengambil langkah preventif demi terwujudnya ketertiban sebuah perkawinan. Yaitu dengan adanya pencatatan perkawinan. sebagaimana pasal 5 ayat (1) Kompilasi Hukum Islam (KHI) yang berbunyi "Agar terjamin ketertiban perkawinan bagi masyarakat Islam setiap perkawinan harus dicatat". Perkawinan yang tercatat secara resmi pada instansi berwenang memiliki konsekuensi hukum tehadap istri dan anak. Konsekuensi hukum berkaitan dengan hakhak yang diperoleh seorang istri dan anak, baik berupa nafakah, waris, identitas anak dan lain sebagainya.

Langkah preventif pemerintah dengan adanya pencatatan perkawinan merupakan upanya membentuk keadilan, lebih tepatnya 


\section{Moh. Mujibur Rohman, Mohsi dan Miftahul Ulum}

keadilan gender. Agar setiap wanita yang melangsungkan perkawinan tidak dirugikan dan mendapatkan perlakuan baik dari adanya tindakan hukum utamanya dalam masalah perkawinan. Ketidak adilan gender merupakan sistem dan struktur dimana baik kaum laki-laki maupun perempuan menjadi korban dari sistem tersebut. Tentu perlu diikuti dengan Pemberlakuan system sanksi adalah sebagai wujud dan bukti adanya kepastian hukum pencatatan perkawinan. ${ }^{25}$

Secara eksplisit pencatatn perkawinan memang tidak dijelaskan dalam kitab-kitab fiqh klasik, namun Pencatatan perkawinan sering kali menjadi perbincangan kaum akademisi dalam aspek legitimasi hukum ${ }^{26}$ yang terus dinamis, serta secara implisit pencatatn perkawinan merupakan bentuk manifestasi dari adanya i'län al-nikeäh (mengumumkan perkwinan). Nabi sangat menganjurkan adanya tindakan mengumukan perkawinan, hal ini terbukti dengan adanya hadis Nabi:

"Dicertakan hadiht dari Āmir bin Abdulläh bin Zubair dari bapaknya bahwa Rasulullab SAW. berkata: "Umumkanlah sebuah pernikahan". ${ }^{27}$

Sahnya akad nikah. Artinya, apabila pernikahan tidak diumumkan, maka per-

25 Mohsi, M. Dekonstruksi System Sanksi Dalam Uu No 22 Tahun 1946 Tentang Pencatatan Nikah, Talak dan Rujuk. Reflektika, 13(1) (2018), 84-104.

26 Mohsi, M. Pencatatan Perkawinan Sebagai Rekonseptualisasi System Saksi Perkawinan Berbasis Maslahah. Al-'Adalah: Jurnal Syariah dan Hukum Islam, 4(2) (2019), 134-148.

${ }^{27}$ HR Imam Ahmad yang dianggap shoheh oleh Imam Hakim. nikahan tersebut tidak sah, bahkan menurut pendapat sebagian ulama, yang membedakan antara pernikahan dan perzinaan adalah bahwa pernikahan diumumkan sedangkan perzinaan tidak diumumkan (Mustika, 2011: 54). Ulama fiqh (fuqahä) umumnya berpendapat bahwa hukum mengumumkan perkawinan bukanlah merupakan syarat, rukun, ataupun kewajiban dalam sebuah akad perkawinan. Hukum mengumumkan perkawinan adalah yundabu (disunnahkan) Sedangkan menurut imam al-Zuhri mengumumkan perkawinan hukumnya adalah suatu yang fardlu. Menurut pendapat ini, meskipun sebuah pernikahan sudah terpenuhi syarat dan rukunnya, tetapi kalau tidak diumumkan maka pernikahan itu dipisahkan, begitu juga bila dua orang saksinya ikut merahasiakan kepada khalayak ramai, maka pernikahan itu harus dipisah.

Berdasarkan pemahaman ini, spirit dalam membentuk keadilan bagi seorang perempuan dalam perkawinan sudah ada sejak jaman Nabi Saw. Adanya anjuran untuk mengumumkan perkawinan, bertujuan memberi tahu keberlangsungan sebuah pernikahan agar terkesan tidak menjadi rahasia secara aspek sosial.

Tidak bisa dipungkiri, aturan-aturan perkawinan dalam fiqh klasik menganut sistem patriarki, dimana kekuasaan sepenuhnya dalam rumah tangga dimiliki oleh kaum lakilaki. Hal inilah yang membuat banyak perempuan mengalami ketidak adilan dan dis- 
kriminasi dalam rumah tangga. Namun, emansipasi wanita dewasa saat sudah mengalami peningkata, tugas wanita tidak hanya berada dirumah saja, terkadang wanita bekerja melebihi seorang peria bahkan menjadi tulang punggung keluarga karena karier yang dimilki lebih produktif dan lebih berkembang dari pada karier suaminya.

Konsep pembagian kerja dewasa ini, meskipun tidak lagi dipandang sebagai suatu yang ketat dan harus membatasi peran kaum wanita hanya dalam lingkup rumah tangga, namun hal tersebut tidak serta merta membagikan fungsi dan tanggung jawab kaum wanita dalam urusan rumah tangga. Bahkan banyak kasus ditemukan fungsi dan peran seorang wanita dalam rumah tangga bertambah akibat keikut sertaan mereka dalam kegiatan yang produktif. Keterlibatan kaum wanita ini didorong oleh keinginan kaum wanita dalam memenuhi kebutuhan hidup keluarganya ${ }^{28}$

Adanya peran perempuan dalam rumah tangga, tidak bisa dilepas begitu saja secara hukum. Perempuan tetap harus mempunyai kedudukan yang sama serta tidak boleh mengalami diskriminasi dalam hal keadilan. Oleh karenanya perncatatan

28 Ariwidodo, Eko. kontiribusi Pekerja Perempuan Pesisir Sektor Rumput Laut di Bluto Kabupaten Sumenep. Nuansa; Jurnal Penelitian Ilmu Sosial dan Keagamaan Islam, Vol. 15, No. 2, 329-356. 19 April 2020.http://ejournal.iainmadura.ac.id/index.php/nua $\mathrm{nsa} /$ article/view/1389/1017 perkawinan yang dalam Islam sudah ditegakkan secara implisit melalui i'lān al-nikeāh (mengumumkan perkawinan) spirit penegakannya sangat dianjurkan oleh Nabi Saw. Maka adanya pencatatan perkawinan harus dipandang sebagai bentuk maslahah dalam menjamin terwujudnya ketertiban sebuah perkawinan, sebagai langkah preventif yang dilakukan pemerintah agar kaum perempuan tidak mengalami diskriminasi serta mendapatkan keadilan gender secara hokum.

\section{Simpulan}

Nikah bawah tangan merupakan entitas kebudayaan yang berjalan di Indonesia. Apabila Pelaksanaannya tetap mengacu kepada ketentuan-ketentuan hukum fiqh klasik, yaitu terpenuhinya syarat dan rukum perkawinan, maka perkawinan sah. Namun menjadi tidak sah kalau mengandung mudharat atau dampak negatif.

Fatwa tersebut sesuai dengan semangat keadilan gender. Karena dalam fatwa tersebut masih memberikan rekomendasi ketata tentang pentingnya pencatatan perkawinan, mengingat kemungkinan-kemungkinan yang terjadi apabila tidak adanya pencatatan perkawinan. Adanya kemungkinan dampak negatif yang akan ditimbulkan, seperti tidak terpenuhinya hak-hak mereka berupa nafkah atau hak waris, serta mungkinnya persengketaan yang 


\section{Moh. Mujibur Rohman, Mohsi dan Miftahul Ulum}

akan terjadi. Sehingga pencatatan perkawinan menjadi urgen sebagai bentuk menjaga keadilan gender dan hak-hak para keluarga, dalam hal ini istri dan anak.

Pencatatan perkawinan merupakan langkah preventif yang dilakukan pemerintah untuk menjamin terwujudnya ketertiban sebuah perkawinan. Karena perkawinan yang tidak dicatatat akan menimbulkan dampak negatif atau mudarat utamanya kepada istri dan anak yang dilahirkan, seperti hilangnya hubungan perdata anak dengan bapaknya, hilangnya hak ayah atas waris serta nafakah jika terjadi perselisihan dan istri tidak diakui secara sah berdasarkan hukum perundangundangan. Pencatatan perkawinan dianggap sebagai langkah preventif (pencegahan) terjadinya kemudaratan serta untuk melindungi kaum wanita dari diskriminasi dan memberikan keadilan.

\section{Daftar Pustaka}

Al-'Asqalānī, Ibn Hajar. Bulügh al-Marām fì Adillat al-Abkām. Surabaya: Nurul Huda. T.t.

Al-Ahdal, Abi Bakar bin Abi al-Qāsim. alFaräid al-Babiyah 'alā Naz̧hmi Qawäid alFiqhiyah. Pasuruan: Pustaka Sidogiri, 2009.

Al-Bājūrī, Ibarāhīm. Hāshiyah al-Bājūirì, Juz. 2. Surabaya: Imaratullah, T.t.

Al-Bukhārī, Abu Abdillah Muhammad bin Ismāil bin Ibrāhīm bin Mughīrah bin Bardizbah. Sabīh Bukhärì. Beirut: Dar al-Kutub al-'Ilmiyah, 2013.

Al-Burhānī, Muhammad Hishām. Sadd alDharā' fi Shariat al-Islämiyah. Damaskus: Dār al-Fikr, 1985.
Ali, Atabik. \& Muhdlor, Ahmad Zuhdi. AlAsbri; Kamus Kontemporer Arab Indonesia. Yogyakarta: Multi Karya Grafika, t.t.

Al-Jawzìyah, Ibn al-Qayyim. I'lam alMuwāq"in 'an Rabb al-'Alamin. Vol. 6. t.tp: Dār Ibn al-Jawzī, 2004.

Al-Jurjāwīi, Ali Ahmad. Hikmat al-Tasyrì wa Falsafatuhu, Juz. 2. Beirut: Dār al-Fikr, 2003.

Al-Qarāfî, Shihāb al-Dīn Ahmad bin Idrīs alSonhajī. Sharh Tanqih al-Fushül fi 'Ilmi al-Ushül.t.tp: t.p, 2000.

Al-Qur'ān.

Al-Suyūthī, Jalāl al-Dīn Abd Rahmān bin Abī Bakar.. al-Asbah wa al-Naz̧äair. Semarang: Pustaka Semarang, t.t.

Al-Syawkānī, Muhammad bin 'Ali. Irsyād alFubūl ilà Tahqĩq al-baqq min Ilm alUshül, Juz. 2. Riyad: Dar al-Fadilah, 2000.

Al-Zuhailī, Wahbah. Ushül al-Figh al-Islamì. Juz. 1\&2. Damaskus: Dar al-Fikr, 1986.

Ariwidodo, Eko. Kontribusi Pekerja Perempuan Pesisir Sektor Rumput Laut di Bluto Kabupaten Sumenep. Nuansa; Jurnal Penelitian Ilmu Sosial dan Keagamaan Islam, Vol. 15, No. 2, 329-356. 19 April

2020.

http://ejournal.iainmadura.ac.id/index .php/nuansa/article/view/1389/1017

Asmawi. Perbandingan Ushul Figh. Jakarta: Sinar Grafika Offset, 2011.

Dahlan, Abd. Rahman. Ushul Fiqh. Jakarta: Amzah, 2014.

Departemen Pendidikan Nasional. Kamus Besar Babasa Indonesia. Jakarta: Gramedia Pustaka Utama, 2008.

Djubaidah, Neng. Pencatatan Perkawinan dan Perkawinan Tidak Dicatat Menurut Hukum Tertulis di Indonesia dan Hukum Islam. Jakarta: Sinar Grafika, 2012.

Firdaus, Ali. Pelaksanaan Tugas Pembantu Pegawai Pencatat Nikah Pasca Instruksi Dirjen Bimas Islam Nomor DJ.II/1 Tahun 2015. Ijtimaiyya; jurnal Pengembangan Masyarakat Islam, Vol. 10, No. 2, 241-272. 7 April 2020. http://ejournal.radenintan.ac.id/index .php/ijtimaiyya/article/view/2363 
Kurniawati, Vivi. Nikah Siri. Jakarta: Rumah Fiqih Publishing, 2019.

Marsal, Arif. \& Parlyna, Ryna. Pencatatan Perkawinan; Antara Rukun Nikah dan Syarat Administratif. an-Nur, Vol. 4, No.1, 41-55. 4 April 2020. http://ejournal.uin.suska.ac.id/index.p $\mathrm{hp} /$ annur/article/download/2052/13 92,2015.

Mohsi, Mohsi. Dekonstruksi System Sanksi Dalam UU No 22 Tahun 1946 Tentang Pencatatan Nikah, Talak dan Rujuk. Reflektika, 2018, 13.1: 84-104. . "Pencatatan Perkawinan Sebagai Rekonseptualisasi System Saksi Perkawinan Berbasis Maslahah”. Al'Adalah: Jurnal Syariah dan Hukum Islam, 2019, 4.2: 134-148.Murata, Sachiko. The Tao Of Islam. Bandung: Mizan. 1999.

Mustika, Dian. Pencatatan Perkawinan dalam Undang-Undang Hukum Keluarga di Dunia Islam. Inovatif; Jurnal Ilmu Hukum, Vol. 4. No. 5, 52-64. 11 April $2020 . \quad$ https://onlinejoual.unja.ac.id/jimih/article/view/53 $\underline{4}$

Peraturan Pemerintah Nomor 9 Tabun 1975 Tentang Pelaksanaan Undang-Undang Nomor 1 Tabun 1974 Tentang Perkawinan.

Sholeh, M. Asrorun Ni'am. Metodologi Penetapan Fatwa Majelis Ulama Indonesia; Penggunaan Prinsip Pencegahan dalam Fatwa. t.tp: Emir, 2016.

Shomad, Abd. Hukum Islam; Penormaan Prinsip Syariah dalam Hukum Indonesia. Jakarta: Kencana Prenada Media Group, 2012.

Susanti, Dyah Ochtorina. \& Shoimah, Siti Nur. Urgensi Pencatatan Perkawinan (Perspektif Utilities). Rechtidee, Vol. 11. No. 2, 166-181. 7 April 2020. http://journal.trunojoyo.ac.id/rechtid ee/article/view/2428/2073

Syafe'i, Rachmat. Ilmu Ushul Fiqh. Bandung: CV Pustaka Setia, 2010.
Syahuri, Taufiqurrohman. Legislasi Hukum Perkawinan di Indonesia; Pro-Kontra Pembentukannya Hingga Putusan Mabkamah Konstitusi. Jakarta: Kencana Prenada Media Group, 2013.

Syarifuddin, Amir. Ushul Figh. Juz. 1\&2. Jakarta: Kencana Prenada Media Group, 2011.

Tim Redaksi Nuansa Aulia. Kompilasi Hukum Islam. Bandung: Nuansa Aulia, 2015.

Undang-Undang Republik Indonesia Nomor 22 Tahun 1946 Tentang Pencatatan Nikah, Talak dan Rujuk.

Undang-Undang Republik Indonesia Nomor 7 Tabun 1984 Tentang Pengesahan Konvensi Mengenai Penghapusan Segala Bentuk. Diskriminasi Terbadap Wanita.

Wizarah al-Auqāf wa al-Shu'ūn al-Islāmiyah. al-Mausu'ah al-Fiqhiyah, Juz. 41. Kuwait: Wizarah al-Auqāf wa al-Shu'ūn al-Islāmiyah, 2002. 